Marija Javor Briški

Filozofska fakulteta,

Univerza v Ljubljani

marija.javorbriski@ff.uni-lj.si
UDK 821.112.2.09-7"18":81'255.4=112.2=163.6

DOI: $10.4312 /$ vestnik.9.159-170

\title{
NEMŠKI PAVLIHA V PRIMERJAVI S SVOJO PREDLOGO TYLL EULENSPIEGELS WUNDERBARE UND SELTSAME HISTORIEN
}

UVOD

Zbirka smešnih zgodb o Eulenspieglu, ki jo pripisujejo Hermannu Boteju, znanemu spodnjenemškemu avtorju 16. stoletja, je od svojih prvih znanih izdaj, ki so v visokonemškem jeziku izšle okoli 1510/11, 1515 in 1519 v Strassbourgu, doživela mnogo - delno prirejenih - ponatisov. Knjiga je bila tako priljubljena, da so jo že v 16. stoletju prevedli v flamščino, angleščino, francoščino in poljščino (prim. Honegger 1973: 11-116). Slovenski prevod Nemški Pavliha v slovénski obléki. Bukve polne smešnih povest za kratek čas poslovénjene pa je izšel šele leta 1850, saj na Slovenskem zaradi bilingvizma višjih slojev in izobražencev ter visoke stopnje analfabetizma med preprostim ljudstvom za prevode iz nemščine prej ni bilo večjega zanimanja (prim. Hladnik 1992, 1993; Ostanek 1987). Prevod, ki ga je napravil Franc Malavašič (1818-1863) (Kidrič 2013), je postal prava uspešnica, zato so ga od 1859 do 1909 še sedemkrat ponatisnili (prim. Hladnik 1982: 69). Predloga slovenskega besedila pa ni, kot so avtorji doslej navajali (Hladnik 1985: 195; Mohor 2013: 216), nemška izdaja iz leta 1515, temveč priredba Carla Fröhlicha Tyll Eulenspiegels wunderbare und seltsame Historien, ${ }^{2}$ ki je po Johannu Martinu Lappenbergu (1854: 219) izšla leta 1849, torej eno leto pred izidom slovenskega prevoda. O povezavi obeh del priča tudi skoraj identična slika na naslovnici, ki je v slovenski izdaji iz leta 1866 - v nasprotju z naslednjo iz leta 1885 - še ohranjena. Z norčevsko kapo in njegovima značilnima rekvizitoma: s sovo in z ogledalom upodablja glavnega junaka, ki v pomenljivo provokativni pozi in s hudobno-hudomušnim nasmeškom bralcu naznanja svoje vragolije.

Kot je značilno za poznejše Eulenspieglove priredbe (prim. Röcke 1987: 18-21, 213), je tudi Fröhlich svojo adaptacijo prilagodil moralizirajočemu duhu svojega časa. Najbolj očitne razlike opažamo pri izboru zgodb. Od 96 prvotnih historij, ki so zbrane v izdaji iz leta 1515 (Lindow 2003) ter se delno opirajo na literarno tradicijo (Pfaff Amis, Pfaff von dem Kalenberg) in na ustno izročilo (Lindow 2003: 8), je ,nespodobne“ zgodbe

1 Citirano po izdaji iz leta $1866 \mathrm{~s}$ krajšavo PAV.

2 Pri nadaljnjih citatih se uporablja krajšava TE. 
s fekalno motiviko, ${ }^{3}$ historije s seksualno konotacijo, ${ }^{4}$ ter $\mathrm{z}$ upodobitvijo intimnih delov telesa ${ }^{5}$ in fizioloških izločkov, ${ }^{6}$ ki bi lahko izzvale bralčev gnus in njegovo neodobravanje, v glavnem izločil. Izpustil je tudi več zgodb, v katerih so pripadniki klera žrtve Eulenspieglovih napadov ali pa se kažejo v slabi luči, ${ }^{7}$ in zgodbe, ki jih občinstvo zaradi spremenjenega pravnega reda predvidoma ne bi več razumelo. ${ }^{8}$

Po drugi strani pa je Fröhlich dodal zgodbe, ki jih strasburška izdaja ne vsebuje. ${ }^{9}$ (Virov, iz katerih je črpal, na tem mestu sicer ne moremo do podrobnosti navajati.) Pri 59. zgodbi, ki govori o Eulenspieglu, kako je Judu konja prodajal in ga varal, lahko najdemo vzporednice s švabskimi šalami (prim. Aurbacher 1832: 41-42). V želji, da bi izbral „najbolj pravilne“ in „,najboljšs“, je morda tudi sam črpal iz ustnega izročila, čeprav je v predgovoru prav to ostro grajal. Zdi se, da izbor dodanih zgodb v nekaterih primerih nasprotuje zgoraj navedenim načelom, ki so domnevno botrovala izključitvi prvotnih. Tako se npr. v 44. zgodbi Eulenspiegel kot depriviligirani oproda zoperstavlja plemiču, pri 51. zgodbi gre za parodijo spovedi in v 54. zgodbi najdemo opolzke motive (TE 77-79, 87-88, 92-93).

V celoti gledano pa je Fröhlich ohranil kronološko-biografsko zgradbo svoje predloge, značilne za t. i. Schwankroman ${ }^{10}$ (Röcke 2007: 410), ki združuje smešne zgodbe različnih provenienc in jih navezuje na življenje glavnega junaka od rojstva do smrti; njegova življenjska pot pa ga dobesedno popelje na nenehno potovanje, kajti Eulenspiegel, kamorkoli že pride, svoje sogovornike namerno izziva in gre svojo pot. Še po smrti pa se ne pokorava splošno uveljavljenim običajem, ampak ponazarja svojo individualnost in neprilagodljivost, ko se pri pogrebu vrv strga in $\mathrm{v}$ grobno jamo njegova krsta pade pokončno:

„,[...] so legten sie den Sarg auf zwei Seile, um ihn ins Grab zu senken; da brach das eine Seil, das unten bei den Füßen war, entzwei, und der Sarg schoß in das Grab, daß also Eulenspiegel auf den Füßen stand. Sie versuchten, ihn zurecht zu legen; da sagte einer der Dabeistehenden: Lasset ihn stehen, er ist in seinem Leben ein wunderlicher Kauz gewesen, wunderlich will er auch im Tode noch sein." ${ }^{11}$ (TE 149)

3 10., 12., 15., 16., 24., 35., 52., 69., 72., 77., 79., 81., 85., 88., 90., 92. zgodba (Lindow 2003: 30-32, 37-38, 44-48, 49-51, 71-72, 104-106, 152-154, 200-202, 210-211, 221-224, 230-231, 234-235, 243-244, 251-252, 256-257, 260-261).

4 67. zgodba (Lindow 2003: 194-196).

5 84. zgodba (Lindow 2003: 241-242).

6 76. zgodba (Lindow 2003: 217-220).

7 13., 37., 68. zgodba (Lindow 2003: 60-62, 120-123, 212-213).

8 83. zgodba (Lindow 2003: 239-240).

9 44., 51., 53., 54., 55., 58., 59., 60., 61., 62., 66., 67., 72., 76. zgodba (PAV 77-79, 87-88, 90-95, 101-109, $115-119,130-133,140-141)$.

10 Prevod termina bi lahko bil „roman smešnih zgodb“ ali „roman burk“.

11 [...] tako so polegli krsto na dve vrvi, da bi ga spuščali v grob; takrat pa se spodaj pri nogah pretrga vrv, da Eulenspiegel stoji na nogah. Skušali so ga položiti v pravi položaj; na kar eden od tam stoječih pripomne: Pustite ga stati, čuden tič je bil v svojem življenju, čuden hoče biti tudi v smrti. 
Fröhlichova „prirejena, izboljšana in dopolnjena“12 izdaja Eulenspiegla, ki se torej delno razlikuje od publikacije iz leta 1515, je, kot smo že omenili, predloga za Malavašičev prevod Nemški Pavliha. V nadaljevanju bomo po komparativni metodi obravnavali nekatere glavne značilnosti slovenske priredbe v primerjavi z nemško predlogo na vsebinski, strukturni in medijski ravni ter s frazeološkega vidika. Izhajajoč iz predpostavke, da na prevod vpliva družbeno-zgodovinski kontekst, kateremu je namenjen (prim. Stanovnik 2005: 87; Prunč 2007: 54), bomo pokazali, da se je Franc Malavašič pri izboru zgodb in nekaterih vsebinskih modifikacijah prilagodil Bachovemu klerikalnemu absolutizmu (prim. Melik 1987: 167; Žigon/Almasy/Lovšin 2017: 17-18), ki je v 50. letih 19. stoletja $\mathrm{v}$ habsburški monarhiji krojil življenje in mišljenje njenih prebivalcev. Kot je zapisal Francè Kidrič (2013), se Malavašič po spodleteli revoluciji leta 1848 ni več hotel vmešavati v politične in verske zadeve in se je že pred koncem leta 1851 sprijaznil z vnovično uvedbo absolutizma, to stališče pa naj bi tudi vplivalo na njegovo literarno ustvarjanje. Rokopisno cenzuro so po letu 1848 sicer odpravili, vendar je bil tisk še vedno pod državnim nadzorom (prim. Olechowski 2004: 267), tako da bi natisnjeno knjigo, če bi bila preveč svobodomiselna, lahko še naknadno konfiscirali.

Nadalje želimo ugotoviti, ali je Levstikova kritika, ki jo je zapisal v Popotovanju iz Litije do Čateža, češ da je delo ,prestavljeno [...] zelo po vrhu““13 (Levstik 1998: 22), povsem upravičena.

\section{2}

\section{PRIMERJAVA DEL NA VSEBINSKI, STRUKTURNI IN MEDIJSKI RAVNI}

Ko primerjamo predgovore obeh del, lahko ugotovimo, da je slovensko delo sicer delno prilagojeno svoji publiki, namen obeh pa je v glavnem enak: naj bralcu, ki ga mučijo skrbi, žalost, zavist in sovraštvo, služi kot razvedrilo in zdravilo. S prikazom Eulenspieglovih oz. Pavlihovih norčij in hudobij - torej s spoznavanjem stvarnosti, s katero se sooča - pa naj posreduje nauk, ki bralca pripravi na človekovo podlost, nezvestobo ter prevaro in ga usposobi, da bi se ljudem s temi značajskimi lastnostmi lažje zoperstavljal.

Kljub težnji, da bi bralca poučil s satiro in z drastično upodobitvijo zla, je v slovenskem prevodu od 81 zgodb, ki so zbrane v nemški predlogi, izpuščenih $32 .{ }^{14}$ Zdi se, da je prevajalec načrtno izločil domala vse zgodbe, ki vsebujejo bodico, uperjeno proti kleru ali krščanski veri, ${ }^{15}$ v nekaterih zgodbah, kjer v nemški predlogi nastopajo duhovniki, pa jih je nadomestil z drugimi osebami, ki so v družbi 19. stoletja sicer uživale določen

\footnotetext{
12 Gl. naslovnico.

13 V smislu ,površno“ (prim. Pleteršnik 1895: 796).

14 1., 13., 15., 16., 20., 24., 27., 29., 31., 39., 40., 45., 48., 49., 50., 51., 52., 56., 57., 66., 67., 69., 71., 73., 74., 75., 76., 77., 78., 79., 80. in 81. zgodba (TE 3-4, 20-25, 29-33, 40-42, 45-52, 54-55, 69-72, 79-80, 84-90, 95-101, $115-119,123-125,129-130,133-149)$.

15 1., 24., 27., 29., 40., 51., 56., 75., 77., 78., 79., 80., 81. zgodba (TE 3-4, 40-42, 45-47, 48-52, 71-72, 87-88, 95-97, 137-149).
} 
ugled, niso pa bile nedotakljive. Tako npr. v 47. zgodbi slovenske različice ${ }^{16}$ namesto duhovnika ${ }^{17}$ nastopa zdravnik, ki se z etičnega vidika ne kaže v najboljši luči. Malavašič je tudi črtal zgodbe, ki bi preveč očitno osramotile plemstvo ali prikazovale anarhične razmere v državi, ${ }^{18}$ in zgodbe, kjer se Pavliha kot posameznik zoperstavlja socialni nepravičnosti, ${ }^{19}$ izpustil pa je tudi zgodbe, ki jih bralec zaradi nepoznavanja kulturnozgodovinskega ozadja ne bi razumel. ${ }^{20}$

Čeprav slovenski prevod ne vsebuje vseh zgodb, ki jih najdemo v predlogi, pa ostane Pavliha po vzoru nemškega Eulenspiegla (prim. Röcke 1987: 213-251) večni popotnik in šaljivec, ki se v družbo ne integrira ter se iz ljudi norčuje tudi tako, da jim pri tem škoduje. Na udaru so vaščani ali sosedje, ${ }^{21}$ obrtniki, ${ }^{22}$ učenjaki, ${ }^{23}$ mestni oz. državni uslužbenci, ${ }^{24}$ krčmarji, ${ }^{25}$ trgovci ${ }^{26}$ ali pa kmetje. ${ }^{27}$ Pri njegovih dejanjih pa Pavliho vodijo različni vzgibi, bodisi da se odzove na provokacijo drugih ${ }^{28}$ bodisi da drugim kakšno ušpiči iz čiste hudobije. ${ }^{29}$ Istočasno pa razkriva njihovo neprimerno, nemoralno ravnanje ter njihove šibke točke, kot so pohlep, ${ }^{30}$ skopost, ${ }^{31}$ sebičnost, ${ }^{32}$ nepoboljšljivost,${ }^{33}$ zanemarjenje dolžnosti, ${ }^{34}$ lahkovernost ${ }^{35}$ in lažna učenost. ${ }^{36} \mathrm{~S}$ svojim ravnanjem kaže na družbene pomanjkljivosti na področju zdravniške oskrbe ${ }^{37}$ in pravosodja ${ }^{38}$ kakor tudi na zaničevanje kmetov ${ }^{39}$ in ljudi, ki so iz družbe izobčeni. ${ }^{40}$ Nenazadnje pa, enako kakor Eulenspiegel (prim. Bollenbeck 1985: 109-119), tudi Pavliha kritizira nereflektirano rabo jezika, ko

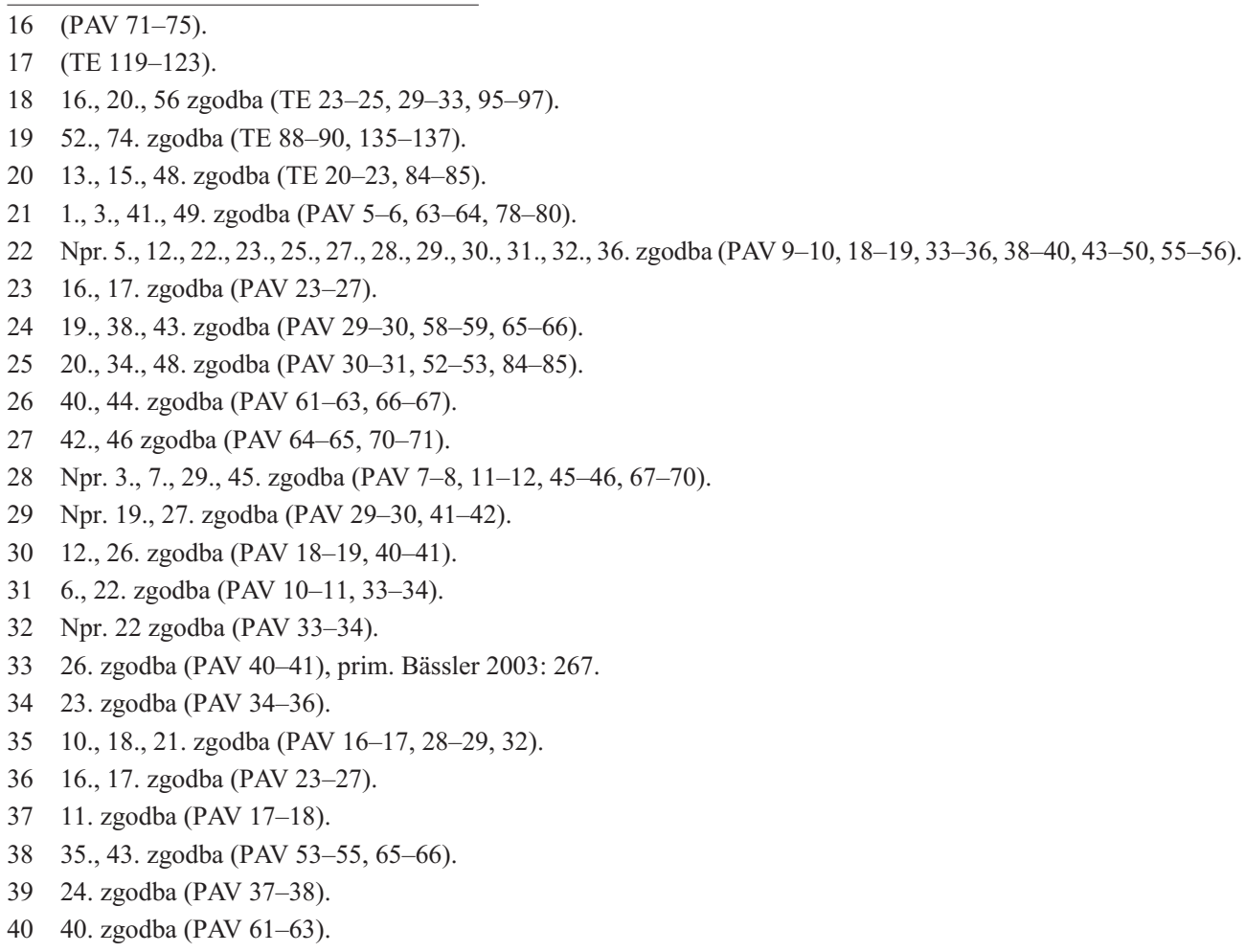


pregovore, reke in izjave razume dobesedno. ${ }^{41} \mathrm{Iz}$ tega sledi, da slovenski prevod, kot bi lahko pomotoma sklepali iz podnaslova, ne služi zgolj bralčevi zabavi.

Izločitev zgoraj navedenih zgodb pa ne omogoča le prilagoditve prevoda na takratne politične razmere in na splošno uveljavljeno miselnost, ki je v 19. stoletju zaznamovala slovenski prostor, temveč delno rahlja tudi prvotno kronološko-biografsko zgradbo. Naracija Pavlihove življenjske poti namreč izključuje začetno in zadnje zgodbe, o nekaterih zadnjih dogodivščinah pa je bralec seznanjen le na kratko v sklepnih mislih (PAV 80). Vrstni red zgodb bi se, razen pri prvih, ki govorijo o vragolijah, ki jih je Pavliha ušpičil v otroštvu (PAV [5]-13), in tistih, ki se navezujejo na prejšnje dogodivščine (npr. PAV 16-17, 22-23, 26-27) načeloma lahko spremenil.

Čeprav se nemška predloga Tyll Eulenspiegels wunderbare und seltsame Historien v primerjavi z izdajo, ki je izšla leta 1515 , ne po kakovosti ne po količini ne more ponašati z bogatim slikovnim gradivom, pa je vendarle opremljena z dvanajstimi bakrorezi. Njihov namen je, kot piše avtor v predgovoru, da tudi preprostemu človeku dodatno ponazarjajo Eulenspieglove burke. Slike, v katerih se dejanja, narativno izražena v besedilu, kondenzirajo na vizualni ravni, naj bi torej zajele bistvo pripovedovanega in pripomogle $\mathrm{k}$ lažjemu razumevanju zgodb. Nemški Pavliha pa razen naslovnice, ki jo najdemo še pri najstarejši dostopni izdaji slovenskega prevoda, ilustracij nima.

Ena glavnih značilnosti Eulenspiegla iz leta 1515 (prim. Bässler 2003: 228-292) kakor tudi Fröhlichove priredbe je, da večina ${ }^{42}$ zgodb temelji na pregovorih ali pregovornih frazah. ${ }^{43}$ Gre za t. i. narativno metaforično inverzijo, ki na osnovi pregovora ali pregovorne fraze generira kratko pripoved, pri tem pa se preneseni pomen v konkretnem kontekstu zgodbe prelevi v svoj prvotni, literalni oz. dobesedni pomen (prim. Bässler 2003: 228229). Osrednje motive pregovorov ali pregovornih fraz, ki reflektirajo navade, izkušnje in prakse ljudi v določenem družbeno-zgodovinskem okolju (prim. Röcke 1987: 248-245), najdemo v naslovu pripovedi ter na začetku ali koncu v samem besedilu zgodb; osrednji motivi pripovedi pa so lahko tudi upodobljeni v slikovnem gradivu (prim. Bässler 2003: 237-238). Na tem mestu sicer ne bomo podrobneje analizirali vseh pregovorov ali pregovornih fraz, ki jih Fröhlichev Eulenspiegel eksplicitno ali implicitno vsebuje, temveč bomo le na posameznih primerih preučili, katerih prevajalskih strategij se je Malavašič

41 Npr. 12., 27., 28. zgodba (PAV 18-19, 41-45).

42 Le pri nekaterih zgodbah Bässler (2003: 335-343) pregovorov ni mogel razbrati oz. izslediti, ker so pregovori kot vsi drugi frazemi $z$ diahronega stališča nagnjeni $k$ demotivaciji. Tako govorci $z$ drugim sociokulturnim ozadjem pomena določenih besednih zvez ne razumejo več (prim. Valenčič Arh 2016: 132-133; Bässler 2003: 263).

43 „Pregovorne fraze se razlikujejo od stalnih besednih zvez po tem, da ne delujejo kot stavčne enote, temveč kot stavek v sestavljenih povedih, pregovori pa tvorijo samostojne povedi in izražajo neko splošno resnico“ (Markič 2013: 236). 
posluževal oz. ali slovenski bralec sploh more v prevodu prepoznati narativno metaforično inverzijo nemških pregovorov oz. pregovornih fraz.

Prva pregovorna fraza se skriva že v samem imenu protagonista Eulenspiegel, ki izvira iz oblike Ulenspiegel, ta pa je izpeljana iz frazema ,ul den Spiegel“. Glagol „ulen“ pomeni ,pomesti, čistiti“, samostalnik „Spiegel“ pa „ogledalo“, v lovskem žargonu „,zadek srnjadi“ ali v spodnji nemščini ,človekova zadnjica“ (prim. Bässler 2003: 239-240, 335). Frazem torej lahko razumemo večplastno: kot poziv sogovorniku, da naj očisti razgaljeno zadnjico, istočasno pa se navezuje na stalno besedno zvezo ,jemandem den Spiegel zeigen bzw. vorhalten“, slov. „kazati komu ogledalo“, kar pomeni „kritično ocenjevati koga, kaj, opozarjati na napake“ (Keber 2011: 624). V tem smislu gre za osrednjo metaforo satire, ki je bila v zgodjem novem veku na splošno razširjena. Če Eulenspiegel ljudem kaže svojo zadnjico, ${ }^{44}$ je njegova gesta zasmehovalna in norčevalna, gledalci pa v narobe svetu prepoznajo svoje obličje. Zaradi dvoumnosti besede „Spiegel“ gre pri frazemu za dvojno metaforo: beseda se lahko razume dobesedno kot „ogledalo“ ali pa v prenesenem pomenu v smislu „zadnjica kot ogledalo“ (prim. Bässler 2003: 240-241). Provokativno sceno, ki udejanja pregovorno frazo, opisuje pripovedovalec v nemškem in slovenskem besedilu:

„Es hob fein säuberlich das Hemdlein hinten hinauf und ließ die Bauern sich in einem neuen Spiegel besehen.“ (TE 5)

„Lepo tiho vzdigne svojo srajčico in pokaže kmétom novo zerkalo (špegel).“ (PAV [5])

Ker frazem obstaja tudi v slovenščini, je njegova narativna metaforična inverzija iz konteksta $\mathrm{v}$ celoti razumljiva tudi slovenskemu bralcu, čeprav „zrcalo“ nima vseh zgoraj navedenih pomenov, ki jih ima „Spiegel“"v nemščini. Pri poimenovanju junaka v slovenskem prevodu pa preneseni pomen imena „Eulenspiegel“ ni več prisoten, kajti „Pavliha“ je „večalna (lahko tudi slabšalna) oblika imena Pavel ${ }^{45 “ “ ~(K e b e r ~ 2007: ~ 205) . ~ „ S l a b s ̌ a l n i ~}$ pomen imenske oblike Pavliha ${ }^{46}$ se je v procesu leksikalizacije uveljavil v poimenovanju komične figure in poimenovanju za ,šaljiv, hudomušen človek“", leksem „pavliha“ pa je bil zabeležen že leta 1825 (Keber 2007: 205-206). Malavašič je za prevod imena glavnega junaka torej izbral ustreznico, ki je v slovenskem družbeno-kulturnem kontekstu že bila ustaljena, tako da je pri bralcu izzvala določena pričakovanja, vendar je bila v primerjavi z nemškim imenom pomensko okrnjena.

Naslov tretje zgodbe nemške predloge „Wie Eulenspiegel nach seines Vaters Tod sich weiter aufführt und auf dem Seil gehen lernt“ (TE 6), vsebuje frazem „,auf dem Seil

44 V 1. zgodbi slovenske izdaje (PAV [5]-6) in 2. zgodbi nemške predloge (TE 4-6).

45 Poudarjeno v originalu.

46 Poudarjeno v originalu. 
gehen“, kar pomeni „biti v negotovem položaju, početi nekaj nevarnega“ (prim. Röhrich 1992b: 1460), to pa Eulenspiegel tudi uprizarja dobesedno. Pri slovenski različici „Kako se Pavliha po očetovi smerti obnaša in se po napeti vervi hoditi uči?" (PAV 6) gre za domala dobeseden prevod, ki sicer ustreza uprizoritvi frazema, vendar se omejuje le na literalni pomen, ker takšna fraza v slovenščini ne obstaja. ${ }^{47}$

Prepletanje med dobesednim in prenesenim pomenom frazemov se v zgoraj navedeni zgodbi nadaljuje, ko Eulenspiegel z vrvi pade v vodo:

,[...] er achtete des genommenen Fußwassers bis über die Ohren weniger, als des Gespöttes der Alten und Jungen, die ihm nachliefen und das Bad segneten." (TE 7)

Frazem „einem das Bad segnen“ dobesedno pomeni „blagosloviti kopel“ in se med drugim nanaša na nekdanji padarjev običaj, da je ljudem v javnem kopališču zaželel prijetno kopel, ${ }^{48}$ uporablja pa se, kot v zgornjem kontekstu, tudi v ironičnem smislu (prim. Röhrich 1991: 130-131). Prevod se glasi:

,$[\ldots]$ to mu je menj v serce segalo, da je čez ušesa v vodo padel, kakor to, de so se mu mladi in stari smejali, ki so za njim tekli in mu osle kazali.“ (PAV 7)

Pregovorni frazem „osle kazati komu“ v smislu „zasmehovati koga“ (Pleteršnik 1994: 851) na slikovit način opisuje posmehovanje ljudi, ne ujema pa se z narativno metaforično inverzijo nemškega frazema, ker se njegova semantična osnova razlikuje od nemške.

Čeprav se v prevodu zaradi narave slovenskega jezika, ki določenih pregovornih frazemov ne pozna, narativna metaforična inverzija domnevno pretežno izgublja, lahko na splošno trdimo, da Malavašič uporablja sočen jezik tudi takrat, ko je v nemški predlogi formulacija bolj suhoparna, npr.:

47 Enako velja tudi za 23. zgodbo „Wie Eulenspiegel zu Nugenstädten im Thüringer Lande den Frauen die Pelze wusch“ (TE 38-39) oz. 18. zgodbo v slovenskem prevodu „Kako Pavliha ženskam kožuhe opêre?“ (PAV 28-29), „einem den Pelz waschen“v prenesenem smislu namreč med drugim pomeni „nekomu nazorno povedati mnenje ali resnico“" (prim. Bässler 2003: 265).

48 Gl. „einem das bad gesegnen: wol bekomme das bad! prosit balneum! rief man einsteigenden zu. häufig aber auch in schlechter bedeutung: es übel bekommen lassen " (http://woerterbuchnetz.de/cgi-bin/WBNetz/wbgui_py?sigle $=$ DWB\&mode $=$ Vernetzung\&lemid $=$ GB00156\#XGB00156) [dostop 11. 03. 2017]. 


\begin{tabular}{|l|l|}
\hline Tyll Eulenspiegel & Nemški Pavliha \\
\hline "Der Rektor schlich beschämt davon“ (str. 35) & $\begin{array}{l}\text { "Vodja je pobral osramoten svoje kopita" } \\
\text { (str. 25) }\end{array}$ \\
\hline "stirbt mein Discipulus" (str. 36) & "če moj učenec gré rakom žvižgat" (str. 26) \\
\hline $\begin{array}{l}\text { "Er ist von sehr grober Art und schwer zu leh- } \\
\text { ren" (str. 37) }\end{array}$ & $\begin{array}{l}\text { "Prav neotesanega zaderžanja je in terdo bučo } \\
\text { ima“ (str. 27) }\end{array}$ \\
\hline "merkte er sich den Weg genau“ (str. 42) & "si tedaj to v glavo vtisne“ (str. 29) \\
\hline "du hast mich zu einem armen Mann gemacht" \\
(str. 62) & $\begin{array}{l}\text { "si me bil na beraško palico spravil" } \\
\text { (str. 40) }\end{array}$ \\
\hline "daß meine Baarschaft zu Ende geht" \\
(str. 78) & $\begin{array}{l}\text { "ker je moja mošnja že skoraj na suhem" } \\
\text { (str. 51) }\end{array}$ \\
\hline "rannte davon“ (str. 103) & "je vzdignil peté" (str. 61) \\
\hline
\end{tabular}

Ponekod Malavašič nemške frazeme prevaja dobesedno - gre za t. i. kalke, ki so za slovenske bralce sicer nenavadni, njihov preneseni pomen pa je iz konteksta razumljiv, npr:

„Ich wollte, daß sie wären, [...] wo der Pfeffer wächst, wenn nur meine Zeche bezahlt wäre.“ (TE 121)

„Hotel bi, da bi bili, [...] kjer poper raste, de bi me le plačali!““(PAV 73)

Frazem ,jem. hinschicken (hinwünschen), wo der Pfeffer wächst“ pomeni „da ga pošiljaš daleč proč“" (Röhrich 1991a: 1159-1160).

\section{$4 \quad$ ZAKLJUČEK}

Na osnovi primerjave slovenskega prevoda Nemški Pavliha in njegove na novo odkrite predloge Tyll Eulenspiegels wunderbare und seltsame Historien lahko ugotovimo, da se je Malavašič v svojem prevodu vsaj na videz prilagodil ideološki situaciji svojega časa, ko se je - upoštevajoč družbene norme, ki jih je narekoval Bachov absolutizem - načeloma izognil povestim, ki bi nasprotovale klerikalno-konzervativnemu duhu takratnega časa, ali pa jih je vsaj ustrezno vsebinsko omilil. Kljub prilagoditvam pa Nemški Pavliha ni namenjen zgolj razvedrilu, da bralec prebrodi vsakdanje tegobe, pod krinko nedolžnih burk se skriva tudi kanček družbene kritike, ki jo pozoren bralec zazna, vendar pa ni tako očitna, da bi vzbujala cenzorjev sum.

Izpustitev zgodb, ki niso ustrezale tedanjim moralnim in političnim nazorom, je sekundarno zabrisala kronološko-biografsko zgradbo, ki je bila značilna za nemško predlogo.

Razen bakroreza, ki še krasi slovensko izdajo iz leta 1866, Nemški Pavliha nima drugih ilustracij, ki bi bralcu na vizualni ravni prikazale ključne motive zgodb. 
Ker Eulenspieglove zgodbe temeljijo na narativni metaforični inverziji, je prevajanje pregovorov ali pregovornih fraz ključnega pomena tudi za ciljno bralstvo. Že iz zgornje analize je razvidno, da Malavašič pri prevajanju frazeme načeloma skuša ohraniti, pri tem pa uporablja različne strategije. Kadar frazemi z isto semantično osnovo v slovenščini obstajajo, jih prevaja skoraj dobesedno. $\mathrm{V}$ tem primeru je narativna metaforična inverzija prisotna tudi v prevodu. Kadar dobesedni prevod posameznih segmentov frazema v slovenščini nima prenesenega pomena kot v izhodiščnem jeziku, izbere ustrezni obstoječi slovenski frazem. V tem primeru postopek narativne inverzije ne deluje več. Slikovitega sloga, ki je na splošno značilen za ljudsko književnost, pa Malavašič v prevodu ne le ohrani, ko frazeme prevaja tudi dobesedno, marveč se metaforično izraža tudi na določenih mestih, kjer je formulacija v predlogi bolj nevtralna.

Čeprav je prevajalec prvotne pregovorne frazeme načeloma ohranil tudi v prevodu ali pa jih je nadomestil s slovenskimi ustreznicami, je pri izbiri imena protagonista ravnal drugače. Odločil se je za ime „Pavliha“, ki je bil ciljni publiki znan kot šaljivec, in tako pritegnil njeno pozornost. Tudi na ta način se je prilagodil slovenskemu bralcu, ker je upošteval njegovo umeščenost v kulturno-zgodovinsko okolje.

Na koncu se vračamo še k Levstikovi kritiki, v kateri prevajalcu očita površen prevod. Glede na zgornje ugotovitve lahko trdimo, da na splošno izrečena negativna ocena ni povsem upravičena. V primerjavi s predlogo Nemški Pavliha sicer res ne vsebuje vseh zgodb, vendar je izločitvi določenih burk botrovala prevajalčeva prilagoditev ideološkim razmeram njegovega časa in je ne gre pripisati njegovi površnosti. Njegov pristop pri prevajanju pregovornih frazemov pa je v glavnem odvisen od možnosti, ki jih ponuja slovenski jezik. Na vprašanje, kako Malavašičev prevod lahko ocenimo na področjih, ki jih nismo obravnavali, pa naj odgovorijo druge raziskave. ${ }^{49}$

\section{SEZNAM LITERATURE}

AURBACHER, Ludwig (1832) Die Geschichte von den sieben Schwaben. Stuttgart: Brodhag. http://reader.digitale-sammlungen.de/de/fs1/object/display/bsb108 60052_00001.html [dostop 03. 06. 2017].

BÄSSLER, Andreas (2003) Sprichwortbild und Sprichwortschwank : zum illustrativen und narrativen Potential von Metaphern in der deutschsprachigen Literatur um 1500. Berlin/NewYork: de Gruyter.

BOLLENBECK, Georg (1985) Till Eulenspiegel - der dauerhafte Schwankheld. Zum Verhältnis von Produktions- und Rezeptionsgeschichte. Stuttgart: J. B. Metzler.

49 Raziskovalni program št. P6-0265 je sofinancirala Javna agencija za raziskovalno dejavnost Republike Slovenije iz državnega proračuna. 
FRÖHLICH, Carl (ur.) (1849) Tyll Eulenspiegels wunderbare und seltsame Historien. Reutlingen: Verlag von Fleischhauer und Spohn. https://books.google.si/books?id $=$ Z6JUAAAAcAAJ\&printsec $=$ frontcover\&hl=sl\&source=gbs_ge_summary_r\&cad $=0 \# \mathrm{v}=$ onepage \&q\&f=false [dostop 07. 03. 2017] [TE $]$.

GRIMM, Jacob in Wilhelm (1854-1961) Deutsches Wörterbuch von Jacob und Wilhelm Grimm. Leipzig: S. Hirzel. http://woerterbuchnetz.de/cgi-bin/WBNetz/wbgui_ py?sigle=DWB [dostop 11. 06. 2017] [DWB].

HLADNIK, Miran (1982) Dolga humoristična proza za „čas kratenje Slovencom“. XVIII. SSJLK: Zbornik predavanj. Ljubljana: Filozofska fakulteta Univerze v Ljubljani, 63-81. HLADNIK, Miran (1985) „Svobodno po nemškem poslovenjeno“ (Popularni prevedeni žanri 19. stoletja). Drago Bajt (ur.) France Prešeren v prevodih. Ljubljana: Društvo slovenskih književnih prevajalcev, 191-199.

HLADNIK, Miran (1992) Vloga prevoda v slovensko-nemški literarni tekmi. XXVIII. SSJLK: Zbornik predavanj. Ljubljana: Filozofska fakulteta Univerze v Ljubljani, 109-119. http://www.ijs.si/lit/prevodsl.html [dostop 31. 03. 2017].

HLADNIK, Miran (1993) Der Einfluss des Bilinguismus auf die Auswahl der zu übersetzenden narrativen Gattungen: (Am Beispiel slowenischer Literatur). Armin Paul Frank/Kurt-Jürgen Maßß/Fritz Paul/Horst Turk (ur.) Übersetzen, verstehen, Brücken bauen: Geisteswissenschaftliches und literarisches Übersetzen im internationalen Kulturaustausch. Berlin/Bielefeld/München: Erich Schmid, 801-810. http://www. kakanien.ac.at/beitr/fallstudie/MHladnik4.pdf [dostop 31. 03. 2017], 1-7.

HONEGGER, Peter (1973) Ulenspiegel. Ein Beitrag zur Druckgeschichte und zur Verfasserfrage. Neumünster: Karl Wacholtz Verlag.

KEBER, Janez (2007) Pavle je Pavel, a ni bil Savel, tudi ni Peter in Pavel ne Peter ali Pavel ne pavliha. Merkurjev zbornik. Ljubljana: ZRC SAZU, 203-215.

KEBER, Janez (2011) Slovar slovenskih frazemov. Ljubljana: Založba ZRC.

KIDRIČ, Francè (2013) Malavašič, Franc (1818-1863). Slovenska biografija. Ljubljana: Slovenska akademija znanosti in umetnosti, Znanstvenoraziskovalni center SAZU, s. p. http:/www.slovenska-biografija.si/oseba/sbi344153/\#slovenski-biografski-leksikon [dostop 01. 04. 2017].

LAPPENBERG, Johann Martin (1854) Ausgaben ohne Jahr, aus dem 19. Jahrhunderte. Johann Martin Lappenberg (ur.) Dr. Thomas Murners Ulenspiegel. Leipzig: T. O. Weigel, 217-220.

LEVSTIK, Fran (1998) Popotovanje iz Litije do Čateža. Fran Levstik. Izbrano delo. Ljubljana: DZS, 5-33.

LINDOW, Wolfgang (ur.) (2003) Ein kurtzweilig Lesen von Dil Ulenspiegel. Nach dem Druck von 1515. Stuttgart: Philipp Reclam jun.

MARKIČ, Jasmina (2013) Razvoj sodobne frazeologije v Španiji. Będkowska-Kopczyk, Agnieszka i. dr. Frazeološka simfonija : sodobni pogledi na frazeologijo. Ljubljana: Založba ZRC, 235-243. 
MELIK, Vasilij (1987) Bachov absolutizem. Enciklopedija Slovenije. Knj. 1. Ljubljana: Mladinska knjiga, 167.

MOHOR, Miha (2013) Priredbe literarnih del za mladino. Revija za elementarno izobraževanje, letn. 6, št. 2-3, 213-221.

Nemški Pavliha v slovénski obléki. Bukve polne smešnih povest za kratek čas poslovénjene (1866) Ljubljana: Janez Giontini. http://data.onb.ac.at/ABO/\%2BZ229107303 [dostop 01. 03. 2017]. [PAV].

Nemški Pavliha v slovenski obleki. Knjižica polna smešnih povestij za kratek čas. (1885) Ljubljana: Janez Giontini. http:/www.dlib.si/?URN=URN:NBN:SI:DOC-32108RZ1 [dostop 01. 03. 2017].

OLECHOWSKI, Thomas (2004) Die Entwicklung des Preßrechts in Österreich bis 1918. Ein Beitrag zur österreichischen Medienrechtsgeschichte. Dunaj: Manzsche Verlags- und Universitätsbuchhandlung.

OSTANEK, France (1987) Analfabetizem. Enciklopedija Slovenije. Knj. 1. Ljubljana: Mladinska knjiga, 74.

PLETERŠNIK, Maks (1894) Slovensko-nemški slovar. Prvi del A-O. Ljubljana: Knežoškofijstvo. https://www.dlib.si/?URN=URN:NBN:SI:DOC-E0VZSRMG [dostop 11. 06. 2017].

PLETERŠNIK, Maks (1895) Slovensko-nemški slovar. Drugi del P-Ž. Ljubljana: Knežoškofijstvo. https://www.dlib.si/?URN=URN:NBN:SI:DOC-E0VZSRMG [dostop 11. 06. 2017].

PRUNČ, Erich (2007) Interdisciplinarnost in raziskovalna povezanost. Karmen Teržan Kopecky (ur.) Slovenski prevodi nemških besedil v obdobju avstro-ogrske monarhije-znanstvene refleksije. Maribor: Filozofska fakulteta, 53-71.

RÖCKE, Werner (1987) Die Freude am Bösen. Studien zu einer Poetik des deutschen Schwankromans im Spätmittelalter. München: Wilhelm Fink Verlag.

RÖCKE, Werner (2003) Schwankroman. Jan-Dirk Müller idr. (ur.): Reallexikon der deutschen Literaturwissenschaft. Knj. III. Berlin/New York: de Gruyter.

RÖHRICH, Lutz (1991) Das große Lexikon der sprichwörtlichen Redensarten. 1. knj. Freiburg im Breisgau: Herder.

RÖHRICH, Lutz (1992a) Das große Lexikon der sprichwörtlichen Redensarten. 2. knj. Freiburg im Breisgau: Herder.

RÖHRICH, Lutz (1992b) Das große Lexikon der sprichwörtlichen Redensarten. 3. knj. Freiburg im Breisgau: Herder.

STANOVNIK, Majda (2005) Slovenski literarni prevod: 1550-2000. Ljubljana: Založba ZRC SAZU.

VALENČIČ ARH, Urška (2016) Was haben Feuertaufe, Deckung und Stellung gemeinsam? - Einigen Phrasemen aus dem Soldatenalltag auf der Spur. Vestnik za tuje jezike 8, št. 1, 131-149. 
ŽIGON, Tanja/Karin ALMASY/Andrej LOVŠIN (2017) Vloga in pomen prevajanja učbenikov v 19. stoletju: kulturnozgodovinski in jezikovni vidiki. Ljubljana: Znanstvena založba Filozofske fakultete Univerze v Ljubljani.

\section{POVZETEK}

Upoštevajoč družbenozgodovinsko ozadje ciljnih bralcev, članek z vsebinskega, strukturnega, medijskega in frazeološkega vidika primerja slovenski prevod Nemški Pavliha z njegovo na novo odkrito predlogo Tyll Eulenspiegels wunderbare und seltsame Historien.

Ključne besede: Pavliha, Eulenspiegel, prevod, frazemi, književnost 19. stoletja.

\section{ABSTRACT}

Nemški Pavliha in Comparison to its Original, Tyll Eulenspiegels wunderbare und seltsame Historien

With sociohistorical background of the target audience in mind, the article compares the Slovene translation Nemški Pavliha with its newly rediscovered original, Tyll Eulenspiegels wunderbare und seltsame Historien, in terms of content, structure, media, and phraseology.

Key words: Pavliha, Eulenspiegel, translation, idioms, $19^{\text {th }}$ century literature.

\section{ZUSAMMENFASSUNG}

Nemški Pavliha im Vergleich zu seiner Vorlage Tyll Eulenspiegels wunderbare und seltsame Historien

Unter Berücksichtigung des soziohistorischen Hintergrundes der Zielleser befasst sich der Beitrag auf inhaltlicher, struktureller, medialer und phraseologischer Ebene mit dem Vergleich der slowenischen Übersetzung Nemški Pavliha und seiner wiederentdeckten Vorlage Tyll Eulenspiegels wunderbare und seltsame Historien.

Schlüsselwörter: Pavliha, Eulenspiegel, Übersetzung, Phraseme, Literatur des 19. Jahrhunderts. 